\section{Anticipating the anti-prion protein?}

$\mathrm{S}_{\mathrm{IR}}-\mathrm{A}$ host-encoded prion protein $(\mathrm{PrP})$ is crucial in the pathogenesis of transmissible spongiform encephalopathies, such as scrapie and scrapie-like diseases in man and animals ${ }^{1}$. The PrP gene is highly conserved in evolution and contains a single open reading frame (ORF) located within a large exon. Several mutations in the human homologue PRNP gene were found in patients with familial Gerstmann-Sträussler-Scheinker's syndrome (GSS) and Creutzfeld-Jakob disease (CJD).

While analysing PrP complementary DNA sequences with the DNA Strider computer program ${ }^{2}$ I found a large overlapping ORF in the DNA strand opposite to the PrP transcriptional unit. The deduced aminoacid sequence of the prospective encoded protein was unique. Its hydropathy $\operatorname{plot}^{3}$ is almost a mirror image of that of the PrP (see figure). For simplicity the name of anti-PrP is used in reference to this putative protein.

This ORF may be of biological importance first, because it is as large as the PrP ORF. Second, none of the differences in PrP

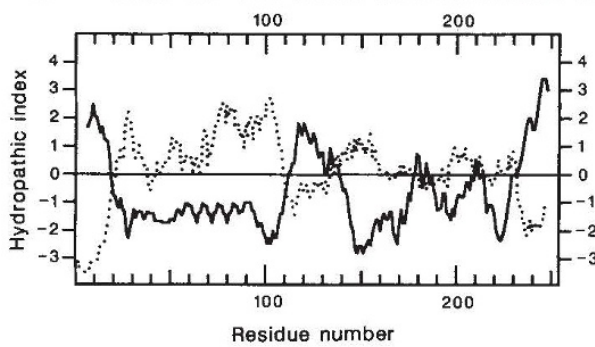

Hydrophobicity plots ${ }^{3}$ of human PrP (solid line) and antiPrP (dot line) proteins generated by the DNA Strider computer program ${ }^{2}$. Numbers on the left and right indicate hydrophobicity index. Numbers above and below indicate amino acid positions in the PrP sequence.

scyucrees foumd in pationts or animals re sulted in additional stop codons in this ORF. It should be noted, however, that mutations found in GSS patients ${ }^{4,5}$ in codons 102 and 117 of the PRNP gene produced amino-acid changes in the anti-PrP, whereas mutations found in CJD patients $s^{6,7}$ in codon 178 and 200 did not. Third, there are ATG or CTG codons at the beginning of this ORF which could serve as translation initiation codons ${ }^{8}$. Fourth, existing data on PrP gene expression do not exclude expression of the anti-PrP gene because only double-stranded DNA probes were used to detect PrP messenger RNA ${ }^{1}$. Obviously, only direct experimental analysis of infected and uninfected cells and tissues with single-stranded probes will show whether the anti-PrP gene is expressed.

The expression of the anti-PrP gene would introduce a new player, present a different view of scrapie infection, and raise new and important questions. Do PrP and anti-PrP proteins interact in infected cells ${ }^{9}$ ? Do GSS mutations, which, unlike CJD mutations, result in amino-acid changes in both proteins, explain the differences between the two diseases? Do RNA unwindase ${ }^{10}$, capable of modifying double-stranded RNA substrates, produce changes in complementary PrP and anti-PrP mRNAs, thus altering the proteins? PrP ORF clearly warrants a search for the prospective encoded protein, especially in view of its potential role in transmissible spongiform encephalopathies.

\section{Department of Psychiatry and \\ Behavioral Science, \\ State University of New York at Stony Brook,}

New York 11794-8101, USA

1. Prusiner, S. B. A. Rev. Microbiol. 43, 345-374 (1989). 2. Marck, C. Nucleic Acids Res. 16, 1829-1836 (1988).

3. Kyte, J. \& Doolittle, R. F. J. molec. Biol. 157, 105-132 (1982).

4. Hsiao, C. et al. Science 250, 1587-1590 (1990).

5. Doh-ura, K. et al. Biochem. biophys. Res. Commun. 163 974-979 (1989).

6. Goldfarb, L. G. et al. Lancet 337, 425 (1991)

7. Goldgaber, D. et al. Expl. Neurol. 106, 204-206 (1990)

8. Prats, H. et al. Proc. natn. Acad. Sci. U.S.A. 86 , $1836-1840$ (1989)

9. Brentani, R. R. J. theor. Biol. 135, 495-499 (1988). 10. Lamb, R. A. \& Dreyfuss, G. Nature 337, 19-20 (1989).

\section{Perceiving depth}

$\mathrm{S}_{\mathrm{IR}}$ - In his News and Views article, (Nature 349, 365-366; 1991) B. J. Rogers comments that B. G. Cummings, E. B. Johnston and A. J. Parker show conclusively (Nature $349,441-413 ; 1991$ ) that the human visual system is not able to use vertical disparities in computing three-dimensional shape. But there is more to three-dimensional perception than having two eyes and binocular stereopsis.

The advantages of binocular vision became apparent to me when I was temporaily blind inene eye-with depthperesp tion lost, ordinary household tasks were no problem because I was in a familiar environment, but I did notice difficulty when hanging kitchen implements on hooks at arm's length. The solution was simple. With the object held out towards the hook it was only necessary to turn my head slightly to the side, displacing the apparent relative positions of object and hook, and, in effect, making one eye record the two images normally seen by two for depth to be assessed correctly so the utensils could be hung.

Since reading the two articles I have now checked by closing one eye and repeating the experiment but moving my head up and down slightly to give vertical displacement of the image. The method still works.

In most experiments on vision the visual system is held still. Fortunately, in real life it is not, and practical problems are much

Yeolmbridge House,

M. LAZARIDES

Nr Launceston,

Cornwall PL15 8TH, UK
In conclusion, the existence of a long antieasier to solve.
Oceanic disjunctions

SIR - Long-distance separations (disjunctions) in the geographical distributions of animals and plants are not uncommon ${ }^{1}$. Most result either from long-distance dispersal or from extinction, leaving widely separated relicts. Disjunct distributions between oceanic islands in different oceans are rarer and more surprising. Valdebenito et al.'s claim $^{2}$ to have found a new one in the disjunction of Peperomia (Dicotyledons, Piperaceae) is a little out; this disjunction was first identified by Skottsberg 45 years ago $^{3}$. Groves ${ }^{4}$ lists Peperomia berteroana tristanensis as "possibly native" to the Tristan da Cunha archipelago in the Atlantic, so the morphological evidence ${ }^{1}$ of its distinction from the Juan Fernandez populations in the Pacific is welcome.

Another biogeographic connection between the Tristan da Cunha archipelago and a Pacific archipelago has been known for some time. The subgenus Trogloscaptomyza of Scaptomyza (Diptera, Drosophilidae) is found only on Nightingale Island in the Tris$\tan$ archipelago and on several islands of the Hawaiian archipelago ${ }^{5}$. This disjunction was first noted by Hackman ${ }^{6}$, who thought it might be a relict distribution. The suggestion that it arose from long-distance dispersal by birds was first made in 1981 (ref. 7), and indeed such dispersal seems to have been important in the spread of Scaptomyza round the world from its origin in Hawaii ${ }^{8}$.

Other disjunct distributions are known exclusively across oceanic islands. For instance Trochetiopsis (Dicotyledons, Sterculiaceae) occurs only on St Helena in the Atlantic (two species) and its closest relative Trochetia only on Mauritius and Réunion Islands in the Indian Ocean (six species) $)^{9,10}$.

Department of Biology,

VIARK VIVILLIATMSON

University of York,

York Y01 5DD, UK

1. Pielou, E. C. Biogeography (Wiley, New York, 1979).

2. Valdebenito, H. A., Stuessy, T. F. \& Crawford, D. J. Nature 347, 549-550 (1990)

3. Skottsberg, C. Acta horti Gotoburg 16, 251-288 (1946).

4. Groves, E. Bull. Br. Mus. nat. Hist., 8, 333-420 (1981). 5. Hardy, E. Insects of Hawaii 12 Diptera: Cyclorrhapha (University of Hawaii Press, Honolulu, 1965).

6. Hackman, W. Acta zool.Fenn. 97, 3-73 (1959).

7. Williamson, M. Island Populations (Oxford University Press, 1981)

8. Williamson, M. Biol J. Linn. Soc. 20, 3-10 (1983).

9. Williamson, M. Nature 309,581 (1984).

10. Mabberley, D. J. The Plant Book (Cambridge University Press, 1987).

\section{Scientific Correspondence}

Scientific Correspondence is intended to provide a forum in which readers may raise points of a scientific character. They need not arise out of anything published in Nature. In any case, priority will be given to letters of fewer than 500 words and five references. 